\title{
Surfaces
}

\section{LITERARY READING: HÖLDERLIN THROUGH HEIDEGGER THROUGH DE MAN}

\section{Sarah Pelmas}

Volume 3, 1993

URI : https://id.erudit.org/iderudit/1065098ar

DOI : https://doi.org/10.7202/1065098ar

Aller au sommaire du numéro

Éditeur(s)

Les Presses de l’Université de Montréal

ISSN

1188-2492 (imprimé)

1200-5320 (numérique)

Découvrir la revue

Citer cet article

Pelmas, S. (1993). LITERARY READING: HÖLDERLIN THROUGH HEIDEGGER

THROUGH DE MAN. Surfaces, 3. https://doi.org/10.7202/1065098ar
Résumé de l'article

Cet essai fait voir comment les enjeux de la théorie littéraire peuvent être envisagés dans le cadre de l'activité de lecture. Est analysée, à travers la lecture qu'offre Paul de Man de la lecture que fait Martin Heidegger de Friedrich Hölderlin, la façon dont Heidegger reprend le langage poétique, l'étymologie et certains examples de Hölderlin dans l'élaboration de sa propre pensée pensée qui demande définitivement à être lue. L’analyse de la réponse de Heidegger à la pensée de Hölderlin pointe vers la nécessité de répondre à la pensée, précisément parce que le langage requiert du lecteur qu'il récupère ces moments même que le langage enregistre constamment comme déjà perdus.
Ce document est protégé par la loi sur le droit d'auteur. L'utilisation des services d'Érudit (y compris la reproduction) est assujettie à sa politique d'utilisation que vous pouvez consulter en ligne.

https://apropos.erudit.org/fr/usagers/politique-dutilisation/ 


\title{
LITERARY READING:
}

\section{HÖLDERLIN THROUGH HEIDEGGER THROUGH DE MAN}

\author{
$\underline{\text { Sarah Pelmas }}$
}

\begin{abstract}
This essay examines how the stakes of literary theory can be understood within the activity of reading. Through Paul de Man's reading of Martin Heidegger's reading of Friedrich Hölderlin, this essay analyzes the way that Heidegger uses Hölderlin's poetic language, examples, and etymology to elaborate his own thought -- thought which ultimately demands to be read. By understanding de Man's response to Heidegger's thinking, we can see how readings must respond to thought precisely because language requires the reader to recover the moments language is always documenting as already lost.
\end{abstract}

\section{RÉSUMÉ}

Cet essai fait voir comment les enjeux de la théorie littéraire peuvent être envisagés dans le cadre de l'activité de lecture. Est analysée, à travers la lecture qu'offre Paul de Man de la lecture que fait Martin Heidegger de Friedrich Hölderlin, la façon dont Heidegger reprend le langage poétique, l'étymologie et certains examples de Hölderlin dans l'élaboration de sa propre pensée -- pensée qui demande définitivement à être lue. L'analyse de la réponse de Heidegger à la pensée de Hölderlin pointe vers la nécessité de 
répondre à la pensée, précisément parce que le langage requiert du lecteur qu'il récupère ces moments même que le langage enregistre constamment comme déjà perdus.

In his essay The Resistance to Theory, Paul de Man traces a history of literary theory and of the specific problems which those two terms -- literary and theory -- might engender. "Theory", he claims, finds itself compromised when it is seen as being synonymous either with philosophy or with criticism, since both rely on "linguistic, that is to say historical and aesthetic, considerations"(7). "Literary" loses its specificity when "it is assumed ... that literariness is another word for, or another mode of, aesthetic response"(9). For de Man, literariness is in fact the place where language itself, through its rhetorical figures, resists its own theorization, and makes literary theory, in a sense, impossible. Resistance is the essence of theory; it is what makes theory both possible and necessary. Thus, professional academic resistance to the presence of literary theory in the university is merely another version of literariness (language's own resistance), and it is this resistance which forms the basis for theory's continued presence in the university.

The goal of literary theory, then, is reading. Nor is this is as simple as it seems: reading is, for de Man, the activity most fraught with impossible conclusions, circular paths, and irredeemable loss. Yet he also makes clear how crucial it is that we explore the stakes of reading, and of response in general. If literary theory has done anything for departments of literature, it has made them less able to teach "simple" close readings. A particularly poignant instance of theory's complication of reading is in our response to Hölderlin's poetry, as de Man shows in his essay "Heidegger's Exegeses of Hölderlin" (Blindness 246-66). We don't read Hölderlin without also reading Heidegger (although the reverse is certainly less true). This is due, in part, to the way in which Heidegger himself reads Hölderlin; but it is primarily due to the way in which Heidegger thinks through the crises of modernity and the question of Being, and the role that Hölderlin plays for him.

But if we read Heidegger for an explication of Hölderlin, we don't really get one. Or at least, not in the way we thought we might. We are left, instead, with a number of questions about the status of Heidegger's texts in relation to Hölderlin's poems, about the role of the critic, about etymology, about the use of examples.[1] In short, Heidegger's essays ask what the stakes of response are. As de Man points out, "everything rests, then, on the intrinsic value of interpretation (249). De Man goes on to claim that Heidegger's analysis does not subscribe to the theory of applying objectivity to a work of art, that it relies on a notion of arbitrariness, which nevertheless elucidates the central issues in Hölderlin's poetry, while also reversing Hölderlin's 
thought. Early in his essay, de Man asks the question which has been a primary impetus behind his reading: "why does Heidegger need to refer to Hölderlin?" (252).

This question is certainly the central one to ask. In "The Origin of the Work of Art," Heidegger makes no reference to Hölderlin at all, except for the epilogue quote. In "Building Dwelling Thinking," Hölderlin is never mentioned. However, many of the lines from that essay also appear in "...Poetically Man Dwells...," an essay expressly about the interpretation of that phrase from a later poem of Hölderlin. It then becomes clear that the former two essays have been about Hölderlin in precisely the same way as the latter. But de Man's question remains: why are these essays about Hölderlin? And a further question might be added: how are they about Hölderlin?

One possible answer is supplied by Heidegger himself, in an early essay. "Hölderlin's poetry was borne on by the poetic vocation to write expressly of the essence of poetry. For us Hölderlin is in a pre-eminent sense the poet of the poet. That is why he compels a decision" ("Hölderlin" 271, italics Heidegger's). So now we might say that Heidegger chooses Hölderlin because he is the poet who can let the truth of the poetic arise from the work in such a way that Heidegger, in thinking through this work, can explore philosophy's relationship to the poetic. Hölderlin is struggling with the questions which are fundamental to a conception of Being, and Heidegger reads Hölderlin as a sort of prophet, whose struggles with existence create poetry as a building, and as a work which allows the struggle of the earth and the world to be waged. De Man writes:

Heidegger is in need in a witness, of someone of whom he can say that he has named the immediate presence of Being. The witness is Heidegger's solution to the problem that had tormented equally poets and thinkers, and even mystics: how to preserve the moment of truth (252).

On the one hand, then, Hölderlin represents the man of singular vision, whose understanding of language grants him an immediate relationship to the truth. Hölderlin's work thus offers a horizon and a ground for Heidegger's hermeneutics.

On the other hand, however, Hölderlin's work is nothing more than something which, above all, demands to be read, and to be preserved. Far from being the essence of the poetic which allows Heidegger to ground his claims about the earth and the struggle for truth, Hölderlin's work is what allows Heidegger to be a thinker, and thus makes room for the fullness of his thinking. In other words, Heidegger chooses Hölderlin because Hölderlin's 
work will slip into the background and allow Heidegger to occupy center stage, while simultaneously making it clear that the work itself has engendered the thinking.

Certainly, both these versions are right, and interdependent in an intimate sense. But it is necessary to read the essays which don't appear to be solely about Hölderlin to understand why this is the case. First, however, it is necessary to understand the moves that de Man himself is making in trying to answer the question. After asking "why Hölderlin?", de Man answers: because Heidegger needs a witness who can testify to what Heidegger himself cannot. De Man continues: "Heidegger's need for a witness is understandable, then, but why must it be Hölderlin?" (254). It is at this point that we realize the first question was never really answered. The need for a witness does not indicate that Hölderlin is the obvious choice. In fact, it might indicate just the opposite, since much of Hölderlin's work seems to be about the impossibility of testifying to having seen Being precisely because that testimony in fact establishes a moment (the "having seen") which is nothing more than pure mediation, a discrete past. Thus, we still wonder "why Hölderlin?" And de Man finally answers: "it is the fact that Hölderlin says exactly the opposite of what Heidegger makes him say"(254-55, italics de Man's). Ultimately, de Man will claim that it is because Hölderlin's work demands specificity and criticism, while Heidegger's is a "meditation upon the poetic [which] is, in fact, a meditation on the ineffable" (263). This double movement, de Man writes, will reinforce philology through new methodologies. So Heidegger needs to read Hölderlin, and to misread him, because his thinking is predicated on the struggle he embodies in his use of Hölderlin's work, and because his "arbitrary" methodology is legitimized only insofar as he can show that this arbitrariness calls into question both itself and the very ground of questioning.

As de Man writes, "for Heidegger, Hölderlin is the greatest of poets ("the poet of poets") because he states the essence (Wesen) of poetry. The essence of poetry consists in stating the parousia, the absolute presence of Being" (250). This is precisely what de Man thinks Heidegger got wrong about Hölderlin; the structure of Hölderlin's poetry, for de Man, works to establish that poetry itself is only mediation, and can never occupy the eternal present necessary to see Being. It can only mediate, or testify (as a witness does, after the fact, thus throwing into doubt the validity of the witnessing), to the realm of language, and thus to the way that language reveals only through representation or concealment of precisely that which it would unconceal. Although Heidegger appeals to Hölderlin because of this very dilemma, de Man thinks that Heidegger's reading must necessarily reverse the moves Hölderlin makes, in order to make him a witness to Being, and a proper historical antecedent to Heidegger's thinking.

In fact, de Man's position as reader seems to necessitate that he read in just this way. Which is to say that, in order to find a position in relation to these 
texts (the poems of Hölderlin, the essays of Heidegger), one must become a pure reader. And the imperatives on the pure reader are that he find for himself a position within the texts he would read. Thus, de Man needs a kind of double-bind in this Heidegger-Hölderlin relationship, which demands to be read. And this is precisely what he finds, necessarily, since that which lets itself be read must also then produce the possibility of reading at all. Thus, if Heidegger finds in Hölderlin an inaugural moment of the poetic, it is partly because Heidegger's thinking makes it the inaugural moment, and partly because Hölderlin's work has, in a sense, been waiting for someone who could think it into its inaugurality. And the same is true of de Man:

Heidegger's thought, above all, demands to be read, and de Man can read only insofar as he is reading Heidegger, and insofar as Heidegger's thought allows reading to continue to occur.[2]

[The now familiar dialectic of blindness and insight] permits [de Man] to characterize various individuals' reading practices in terms of the necessary exclusion that their mode of reading implies, not simply as a form of neglect or ignorance but as the very originating locus of such insight as they achieve or illumination as they can provide.

(Godzich, xxi)

This analysis of de Man's reading practices shows how it is that his assessment of Heidegger provides him with the position from which to assess. If Heidegger is using Hölderlin historically and symbolically as the prophet of Being, and if Hölderlin's poetry turns out to work in precisely the opposite manner to how Heidegger thinks it, a reader is required. If Hölderlin is the poet, Heidegger the thinker, and de Man the reader, then it is the legacy of both de Man and Heidegger that we read.

In a prefatory remark to an address on Hölderlin's Heimkunft, Heidegger writes:

Perhaps every explanation of this poem [Entwurf zu Kolomb] is a fall of snow on the bell. But whatever an explanation can or cannot do, this always applies: in order that what has been purely written of in the poem may stand forth a little clearer, the explanatory speech must break up each time both itself and what it has attempted.

("Remembrance" 234) 
This is at first a description of the function of criticism, but it also clears the ground for Heidegger's own thinking. That the hermeneutic circle must trace the circular path is a given, as perhaps a philosophical a priori might be, and is also a metaphor which prioritizes language and the poetic. The category of the metaphoric brings into proximity language, poetry and thought. So when Heidegger begins and ends an essay with a poem of Hölderlin, as he does in "Remembrance of the Poet," "Hölderlin and the Essence of Poetry," and "...Poetically Man Dwells...," this is in order to assure that he has given us "a fall of snow on the bell." It is also so that we understand we have, in fact, been tracing or following a path. The metaphor of the route through the heavy trees is pervasive in Heidegger's thought, as is evidenced by the (often overlooked) first section of Poetry, Language, Thought, entitled, in English, "The Thinker as Poet." The German title is Aus der Erfahrung des Denkens. Despite the uncertain status of translation within this volume of essays, this mistranslation gets at the root of a problem: "the experience of thought" is taken for "the thinker as poet." The translation not only replaces experience with poetry, but also infuses the title, and thus the section, with an agency it does not require. The English title implies that we are going to get some nice little poems by Heidegger, whereas the German title implies that the experience of thought must manifest itself in the poetic (if, in fact, that is how we read the line-breaks and meter of this piece). The former presents the image of Heidegger, "the thinker," attempting, like Hölderlin, to explore the essence of poetry. The latter presents no image, but rather claims that the essence of thought is the poetic. And that thought approaches the poetic (or experiences the poetic) by way of the metaphoric path through the woods:

Way and weighing

Stile and saying

On a single walk are found.

Go bear without halt

Question and default

On your single pathway bound.

(Thinker 3)

And later: 
When the wind, shifting quickly, grumbles

in the rafters of the cabin, and the

weather threatens to become nasty....

Three dangers threaten thinking.

The good and thus wholesome

danger is the nighness of the singing

poet.

The evil and thus keenest danger is

thinking itself. It must think

against itself, which it can only

seldom do.

The bad and thus muddled danger

is philosophizing. (8)

For Heidegger, then, the goal is not to do philosophy, but to be a thinker. And so this section must explore the possibilities and dangers of thought. Since this is the opening section of this volume (which is also not without its reference to Hölderlin), and the last section is an extended response to one line of Hölderlin's, thought cannot occur without recourse to the poetic. Further, there is no thought outside the poetic; but this is, above all, mere thinking, which is to say thinking Being. "To think 'Being' means: to respond to the appeal of its presencing" (Epilogue 183). This presencing is made within, and as a result of, the absence of the gods, and Heidegger characterizes his writing as "the path of a responding that examines as it listens. Any path always risks going astray, leading astray. To follow such paths takes practice in going" (186). 
The opening and closing sections of this volume, then, show us the path. It begins in the poetic (as an experience of thought), and it ends in the poetic (as an experience of dwelling). The former is Heidegger's, the latter is Hölderlin's, and Heidegger's task here is to follow (and simultaneously to trace) the path from one to the other, the path which will then necessarily lead back to its originating point. This metaphoric path raises the issues of agency (since someone must walk the path), mediation (since the path is both a location and an intermediate atemporality), and language (since paths, above all, trans-late).

The task of thinking here is intimately connected with the call to listen, and to preserve. In order for Heidegger to understand the work Hölderlin gives, he must understand how his listening will also then allow the work to remain a work, insofar as preservation, for Heidegger, is what lets the work be a work.

Being a work, it always remains tied to preservers, even and particularly when it is still only waiting for preservers and only pleads and waits for them to enter into its truth.

\section{("Origin" 67)}

This essay, of course, is not overtly about Hölderlin, nor even about poetry. In fact, it takes its two primary examples from painting and architecture. This is, of course, to tackle questions of instrumentality and representation, over and above questions which a poem might raise about the status of language. Nevertheless, the entire essay is leading, as we anticipate (although we do not perhaps know why), toward poetry; in fact, it drives toward this line : "All art, as the letting happen of the advent of the truth of what is, is, as such, essentially poetry" (72). And then it drives on, toward the final lines, which, in turn, proclaim the origin not only of the art work, but also of the very piece he has just finished.

The origin of the work of art -- that is, the origin of both the creators and the preservers, which is to say of a people's historical existence, is art. (78)

On one level, then, this essay reads as an extended explanation (metaphor being the mode par excellence of explanation) of why Heidegger needs to read Hölderlin. The answer, contrary to what de Man discovered, is that Hölderlin needs to be read, because art demands a hearing, and because Hölderlin's art, above all, precipitates a historical people.[3] Hölderlin's work is the final moment of this essay, which then turns out to have been 
about Hölderlin the whole time, but "about" in the same way that it is "about" Van Gogh or the Greek temple, that "Building Dwelling Thinking" is "about" the bridge or the peasant farmhouse, and that "...Poetically Man Dwells..." is "about" In lieblicher Blaue. We must look, then, at the status of the examples in these essays.

To start at the end, and also the beginning, let's look at Heidegger's treatment of In lieblicher Blaue.[4] It's misleading, of course, to say that Heidegger treats the whole poem. In fact, his interest in this poem extends primarily through the phrase "poetically man dwells." In the early essay, "Hölderlin and the Essence of Poetry," this phrase finds itself the fifth "pointer" in a list which Heidegger uses to think the essence of poetry (and thus why Hölderlin is "the poet of the poet"): "Full of merit, and yet poetically, dwells/Man on this earth" (270). In the late essay, "...Poetically Man Dwells...," he uses this line to explore the nature of the poetic in relation to dwelling, a relationship he has already been exploring in the essay "Building Dwelling Thinking." In the later essay, Heidegger analyzes the question of measure that appears in the poem, and claims that the nature of poetry is one of taking measure, and that poetry is the ultimate building; further, man dwells in that which he builds, and thus man dwells, ultimately, in poetry through measure-taking. (Poetry, of course, is identifiable primarily because it has meter.) The onus of this claim, then, rests on the idea of man taking measure, which Heidegger draws from these lines:

May, if life is sheer toil, a man

Lift his eyes and say: so

I too wish to be? Yes. As long as Kindness,

The Pure, still stays with his heart, man

Not unhappily measures himself

Against the Godhead. Is God unknown?

Is he manifest in the sky? I'd sooner

Believe the latter. It's the measure of man.

Full of merit, yet poetically, man 
Dwells on this earth.

("Poetically" 219)[5]

Heidegger identifies the first moment of measuring when man lifts his eyes, and later, implies that authentic poetry is precisely when "Man/ Not unhappily measures himself/ Against the Godhead." This authenticity is a result of the proximity to the letting happen of truth, which occurs in a pure in-between moment, for Heidegger.

The upward glance passes aloft toward the sky,

and yet it remains below on the earth. The upward

glance spans the between of sky and earth. This

between is measured out for the dwelling of man. (220)

In this case, man finds himself occupying the between position; but in the earlier essay on this same poem, that space was reserved for the poet:

The poet himself stands between the former -- the gods, and the latter -- the people. He is one who has been cast out -- out into that Between, between gods and men. But only and for the first time in this Between is it decided, who man is and where he is settling his existence.

("Hölderlin" 288-89)

Here, the Between is a space which locates itself as the instantiation of a new temporality -- "the time of the gods that have fled and of the god that is coming ... the No-more of the gods that have fled and the Not-yet of the god that is coming" (289). This places the poet at the site of pure mediation, the kind of mediation that determines both temporality and legibility. The distinction of man from poet, or the conflation of the two, here, may be more an indication of the necessary relation to the earth and thingliness. Man (the peasant) must be close to the ordinary objects, and the poet must remain at a distance, in order to be able to think dwelling, or simply to dwell. 
For Heidegger, this mediate moment is the poetic pure experience of Being. For Hölderlin, it seems, this moment is one of death. In the fragmentary poem Wie wenn am Feiertage, the experience of the god is deadly to Semele, although it produces Bacchus.[6] Semele is the figure Heidegger seeks; she is the one who had the pure encounter with the god. But because of that she was killed, and it was only the product of that encounter, Bacchus, who could ascend to the poetic. And the result of this encounter seems to be that poetry can only ever point to an experience it has never had, nor even witnessed, but an experience which nonetheless has engendered it. Similarly, we might read "poetically man dwells" as a lament that, although man is certainly deserving of a purer experience, he is in fact reduced to mediation nonetheless; mediation becomes both a goal and a limitation -- the extent to which man can experience anything at all, and the simultaneous means by which he might bear witness to those experiences.

This seems to be precisely what Heidegger is after, in his position as preserver of the creations of Hölderlin (whom he interprets as both Between and of the Earth). Having read this final essay, we then realize that the intermediate essay "Building Dwelling Thinking" is about the status of mediation, and the central position it must find in our thinking, and thus also in our dwelling. Heidegger, as he does in "The Origin of the Work of Art," subverts our expectations of an example by choosing a bridge as the "built thing" upon which he will reflect ("Building" 152). The first thing we can say about a bridge is that it is between. But Heidegger claims that the bridge is only between insofar as it makes the landscape around it into locations, and is thus itself also a location, not merely a non-space of transition. "The bridge," Heidegger writes, "gathers to itself in its own way earth and sky, divinities and mortals" (153, italics Heidegger's). This gathering is in part a result of the stories Heidegger weaves around the bridge he has created, stories of Germany and its men, whose actions are always in search of this "fourfold" which the bridge gathers in: earth, sky, divinities, mortals. Things which can make room for this fourfold are built because man has a capacity for dwelling. This capacity must precede the building, yet it is only manifest through the built form.

Heidegger's second example is more poignant, perhaps, because more specific: "Let us think for a while," he writes, "of a farmhouse in the Black Forest, which was built some two hundred years ago by the dwelling of peasants" (160). This example is no longer one of the mediate thing, but one of the thing created from the fullness of dwelling. This must, of course, remind us of the example, in "The Origin of the Work of Art," of Van Gogh's painting of the pair of shoes (which Heidegger attributes to a peasant woman):

When [the peasant woman] takes off her shoes late in the evening, in deep but healthy fatigue, and reaches out for them again in the still dim dawn, or 
passes them by on the day of rest, she knows all this [the silent call of the earth, the loneliness of the field-path, uncomplaining anxiety as to the certainty of bread, etc.] without noticing or reflecting. (34)

These examples begin to look like the kind of historical claim that Heidegger tends to avoid in these essays. But in fact, these examples -- along with the Greek temple, the other architectural creation analogous to the Black Forest farmhouse, in that it was created in the fullness of dwelling, by mortals who understood how to forge a relationship with the divinities -- these examples are themselves bridges from one essay to another. Further, they function transitionally, literally moving Heidegger from one site to another. And so we might say that these figures are entirely literal, that they form a kind of touchstone with the earth that allows Heidegger to think his mediating position again. And, far from leading easily into the next moment of the essay, they inevitably lead in several directions at once, forcing us to read in circles, as Heidegger has been thinking in circles.

This is a very difficult journey, because it asks us to move, and yet to dwell and to think. Further, there are radical ellipses in our journey. The path does not merely lead astray, as Heidegger warned us it might; instead, it disappears completely. This disappearance occurs in at least two places, both at the sites of etymological disruptions. The first comes rather early in "The Origin of the Work of Art," where Heidegger claims that the Greeks were able to "experience the Being of beings in the sense of presence," and further, that

Roman thought takes over Greek thought without a corresponding, equally authentic experience of what they say, without the Greek word. The rootlessness of Western thought begins with this translation. (23, italics Heidegger's)

This rootlessness was keenly felt by Hölderlin, and manifests itself in much of his poetry and his theory.[7] Yet proclaiming translation to have been the source of philosophy's problems carries difficulties of its own. Translation is, in one sense, the basis of poetry -- the carrying of the poetic across the gap between the divinities and the mortals is one of the tasks of the poet. Hölderlin's position certainly echoes this worry over the translational loss of access to the authentic:

There seems to be indeed hardly any other choice than to be oppressed by what has been appropriated and by what is positive, or, with violent effort, to oppose as a living force everything learnt, given, positive. 
If we remember Hölderlin's invocation of Semele, we realize that the translational moment occurs when the seer is struck dead and thus gives birth to the poet; the moment of translation, of pure metaphorical experience, is always of the past. The words the poet uses to speak the divine moment are always "appropriated," because not authentically given. But if the foreign is, in some sense, more native to the poet than the familiar, then this "rootlessness of Western thought" is ultimately the basis for thinking dwelling. Heidegger's thought seems to support this; in several places, he implies that distance is precisely what gives us access to thinking, and thus to dwelling. This, of course, contrasts with the peasants, who are so close to (familiar with) their surroundings that they are the epitome of dwelling. The separation seems to be inflicted on the poet and the thinker by virtue of the fact that they have access to language as more than a mere tool:

To be sure, the poet also uses the word -- not, however, like ordinary speakers and writers who have to use them up, but rather in such a way that the word only now becomes and remains truly a word.

("Origin" 47-8)

The danger here is the danger Heidegger has been facing since his opening essay, in which he listed the three dangers to thinking; "the good and thus wholesome danger is the nighness of the singing of the poet." ("Thinker"8). And further, if, as he quotes from Hölderlin, "language [is the] most dangerous of possessions," ("Hölderlin" 273) then man is always threatened with the loss of the possibility of dwelling. We must listen to the singing of the poet -- we are tempted by it, and lured into the beauty of it -- and there is no other access to the truth than thinking poetically (that is, thinking dwelling). However, by listening to the poet, although we are becoming conversation, as Heidegger insists we must, we are also opening ourselves to the temptation to use words in order to use them up, that is, to determine their meaning and function and grant them only that amount of play (277-80). This, it seems, is the trouble with etymology. The history of a word's meaning asks us to make a choice between the current usage (ordinary) and the usages it may have had in other incarnations, in former (and dead) languages. As if the choice were that simple, or had only these minimal ramifications.

Heidegger sets us up to choose the latter (the second place where our path disappears completely) when he gives us the High German and Old English words for Bauen, by way of answering the question: "What, then, does 
Bauen, building, mean?" ("Building" 146). This question seems a little disingenuous, since obviously Bauen does not mean whatever the derivation says. In fact, Heidegger's etymological foray into the word Bauen, and also the word Wohnen, are attempts to connect our understanding of these words with a notion of preserving, so that etymology turns out to be a way of letting these words (and thus the concepts) come into the fullness of their being. The process of thinking which accompanies this journey into dictionary definitions then becomes the fundamental way to "build out of dwelling, and think for the sake of dwelling" (161). But there is a danger in allowing ontological questions to be answered by etymology -- we might be led astray. The words may not achieve their definitions, unless they are allowed the full range of language, which is, of course, only possible through the poetic. Thus it is that we let our poets define our words for us, more readily through metaphor than anything we might consider literal.

Which leads us back to the question, again: why Hölderlin? We shall perhaps never answer it satisfactorily, but one answer which we often overlook is this: he went mad. And the two analyses we began with ("Hölderlin and the Essence of Poetry" and "...Poetically Man Dwells...") both draw from a poem produced during Hölderlin's stay in the asylum. It is certainly no coincidence that Heidegger finds the essence of poetry to be discovered by a man who himself could not bear being a witness. As Semele died for seeing the god, and thus bequeathed the legacy of testifying to Bacchus, so Hölderlin went mad for his vision. His work waited for a preserver, and pleaded and waited for him to enter into its truth ("Origin" 67). Heidegger is clearly trying to accede to the position of preserver, although it's not clear (as de Man has shown) to what extent Heidegger is actually letting the work be a work, and to what extent his thinking is performed at the expense of aletheia in Hölderlin's texts.[8] /pp. 21-22/

That Hölderlin's madness is not an irrelevant issue can be seen in Heidegger's use of Van Gogh's painting. The painting Heidegger chose is certainly not one of Van Gogh's more famous paintings (if we can even say with certainty which painting he meant), and other paintings of shoes or equipmental things might have been found. So why Van Gogh? Perhaps because he too went mad.

It is precisely in great art -- and only such art is under consideration here -that the artist remains inconsequential as compared with the work, almost like a passageway that destroys itself in the creative process for the work to emerge. (40)

In the essays we have looked at here, the only two artists mentioned in the major examples are Hölderlin and Van Gogh. Neither of them can be said to have remained inconsequential in relation to their work. In fact, a certain morbid interest in their work is sparked by the knowledge of their insanity, 
and a school of readings has emerged as a result. Like Hölderlin, Van Gogh is considered to have been touched by some kind of divine vision, which clearly drove him mad.

What is certain about "The Origin of the Work of Art" is that "great art" was not, in fact, under consideration, at least not to the extent we might have expected. What was under consideration was the methodological and emotional demand that thinking, even along circular paths, not find itself to be utterly detached from 'reality', and that a paramount concern for poetry not seem "a symptom of a perverted narcissism and at the same time a confession of inadequate richness of vision" ("Hölderlin" 272-73). And if, as de Man claims, Heidegger did get Hölderlin exactly backwards, is that the reason Heidegger's essays are so moving? Is that the source of the impression that they are our truth, and speak to us about our thought?

The use of Hölderlin, and of the other examples, and of the etymological maneuvers, in Heidegger's essays seems, at base, to be an appeal to pure mediation, in such a way that the examples and the references themselves take on the status of Semele's story; they are fragments, or remnants, or bridges, which cannot ever represent the moment of encounter -- because it cannot be represented, and because it cannot ever be removed whole from the perpetual present in which it must occur. Under these circumstances, then, the question isn't be whether or not Heidegger got Hölderlin right, but how it is that, through the use of Hölderlin, he maintains the tension of the Between: the mediative process which nevertheless preserves within it the loss of the very event which engendered it.

Finally, though, Heidegger's thought, in its circuity, in its preservation of loss, must be read. It is, in its essence, a call to read, of precisely the kind de Man hears through the (relatively new) channels of literary theory. Heidegger highlights for us the moments in which language is at its poetic, its most literary, which are also the moments when the path threatens to disappear. For de Man, these moments are the ones which cannot be determined once and for all through the imposition upon them of a grammatical rule or truth. Rather, these are the moments in which the stakes of reading, and thus also of the tradition of history, philosophy and poetry, are the highest. We stand to lose everything if we think the path must be charted for us in advance. We cannot, finally, know our own position while we read, and that, ironically, is what preserves us; for it necessitates that readers come after us, that we enter into a community of readers, that texts and language can never be "used up," but must instead circulate through a community that endlessly reconstitutes itself.

Schwer verläßt,

Was nahe dem Ursprung wohnet, den Ort. 
(Hölderlin, Selected Verse 150; Heidegger, "Origin" 78)

\section{Sarah Pelmas}

Department of Rhetoric

Surface Page d'Acceuil/Home Page

\section{UC Berkeley}

Berkeley CA 94720

spelmas@uclink.berkeley.edu

\section{Works Cited}

de Man, Paul. "Heidegger's Exegeses of Hölderlin." In Blindness and Insight. 2nd ed. Minneapolis: U of Minnesota Press, 1983. 246-66.

. The Resistance to Theory. Minneapolis: U of Minnesota Press, 1986.

Godzich, Wlad. "Introduction: Caution! Reader at Work!" In Blindness and Insight. xv-xxx.

Heidegger, Martin. "Hölderlin and the Essence of Poetry" and "Remembrance of the Poet". In Existence and Being. Trans. Douglas Scott. Ed. Werner Brock. Chicago: H. Regnery, 1949. 270-91 and 233-69.

. "The Thinker as Poet," "The Origin of the Work of Art," "Building Dwelling Thinking," Epilogue to "The Thing" and "...Poetically Man Dwells...

." In Poetry, Language, Thought. Trans. Albert Hofstadter. New York: Harper \& Row, 1971.

Hölderlin, Friedrich. Essays and Letters on Theory. Trans. Thomas Pfau. Albany: State University of New York Press, 1988.

. Selected Verse. Ed. and Trans. Michael Hamburger (London: Anvil Poetry Press Ltd., 1986). 
[1]In this essay, I will be working primarily from four of Heidegger's essays (although there are any number of others one might choose as well): "Hölderlin and the Essence of Poetry," "The Origin of the Work of Art," "Building Dwelling Thinking," and "...Poetically Man Dwells... ."

[2]It will now be obvious that one of my primary concerns here is the position that is available to me at this point. I am sure I will never answer this (perhaps that is not my job). One of de Man's more disingenuous statements has been that he isn't doing anything everyone else can't also do, and that we should all be reading the texts he discusses, not his discussion. But, of course, once we have read his discussions, we cannot read the texts in the same way. If de Man's work does nothing else, it shows me that a New Critical 'simple' close reading has never really been possible. I think this is a result of the kind of reader de Man has made me, but it may also be a result of the kind of reader Heidegger has made me, or perhaps even Hölderlin has. And the final question for me is why it is that I should consider these texts to be particularly poignant ones, when they are not, strictly speaking, my history (I am not a western European). Whether they have become familiar by being alien (Hölderlin), or whether they have become my tradition by virtue of my own textual history (Heidegger), I cannot decide.

[3]This point is mentioned, and then dismissed, by de Man, when he asks why Heidegger needs Hölderlin as his witness:

There are, to be sure, secondary reasons, of a sentimental and national nature, in [Hölderlin's] favor. Heidegger's commentaries ... are directly linked to an anguished meditation upon the historical destiny of Germany, a meditation that finds an echo in the 'national' poems of Hölderlin. But that is a side issue...

("Heidegger's Exegeses" 254). [4]It is important to note that this poem was not authentically Hölderlin's. Michael Hamburger writes that it was certainly taken from the mad utterances of Hölderlin, but that it was also certainly written by Wilhelm Waiblinger. The importance here is not that it is "unauthentic," but that Heidegger relies so heavily and completely on the precise words of this poem, which must certainly carry with them the image of a mad poet, as if the accuracy of the words which are only possibly Hölderlin's actually attests to the impossibility of a pure experience of Being (Selected Verse 246).

[5]This translation is given line-breaks by Hamburger. The original German has no verses, and reads:

Darf, wenn lauter Mühe das Leben, ein Mensch aufschauen und sagen: so will ich auch sein? Ja. So lange die Freundlichkeit noch am Herzen, die Reine, dauert, misset nicht unglücklich der Mensch sich mit der Gottheit. Ist unbekannt Gott? Ist er offenbar wie der Himmel? dieses glaub' ich eher. Des Menschen Maß ist's. Voll Verdienst, doch dichterisch, wohnet der Mensch auf dieser Erde. (Selected Verse 245)

[6] So fiel, wie Dichter sagen, da sie sichtbar Den Gott zu sehen begehrte, sein Blitz auf Semeles Haus 
Und die göttlichgetroffne gebar,

Die Frucht des Gewitters, den heiligen Bacchus.

(Selected Verse 79) [7]See, for example, Hölderlin's letter to Böhlendorff, in which he writes:

Yet what is familiar must be learned as well as what is alien. That is why the Greeks are so indispensable for us. It is only that we will not follow them in our own, national [spirit] since, as I said, the free use of what is one's own is the most difficult.

(Essays 150, italics Hölderlin's). [8]This is, of course, not a fair statement, since unconcealedness is certainly one of the results of Heidegger's readings. But if these readings are primarily thinking, and Hölderlin's work is more incidental than central (if Hölderlin is more of a transitional example than a central focus), then his poetry can only be seen as the means to unconcealedness, and the means to thinking (dwelling or the poetic). And there is also the related issue (with which de Man also grapples) that Heidegger is taking on the status of philological expert, despite his methodological disavowal of that position. 